\title{
NEW RECORD OF “BATHYMODIOLUS” MAURITANICUS COSEL 2002 FROM THE GULF OF CADIZ (NE ATLANTIC) MUD VOLCANOES
}

\author{
LUCIANA GÉNIO, ${ }^{1,3 *}$ SHANNON B. JOHNSON, ${ }^{2}$ ROBERT C. VRIJENHOEK, ${ }^{2}$ \\ MARINA R. CUNHA, ${ }^{3}$ PAUL A. TYLER, ${ }^{4}$ STEFFEN KIEL ${ }^{5}$ AND CRISPIN T. S. LITTLE ${ }^{1}$ \\ ${ }^{1}$ School of Earth and Environment, University of Leeds, Leeds LS2 9JT, UK; ${ }^{2}$ Monterey Bay Aquarium \\ Research Institute, Moss Landing, California 95039; ${ }^{3}$ CESAM \& Departamento de Biologia, Universi- \\ dade de Aveiro, Campus de Santiago, 3810-193 Aveiro, Portugal; ${ }^{4}$ School of Ocean and Earth Science, \\ National Oceanography Centre, University of Southampton, Southampton SO14 3ZH, UK, ${ }^{5}$ Institute of \\ Geosciences-Paleontology, Christian-Albrechts-University Kiel, 24118 Kiel, Germany
}

\begin{abstract}
The "Bathymodiolus" childressi group is the most geographically diverse assemblage of deep-sea mussel species. In this paper we consider several possible hypotheses to explain the present biogeographic distribution of the "B." childressi species complex. Mussels were collected for the first time from mud volcanoes in the Gulf of Cadiz (NE Atlantic Ocean) during the training through research (TTR) 16 research expedition in 2006. Preliminary observations of the shell features indicate that they belong to the " $B$." childressi species complex, which has been recognized as morphologically and genetically distinct from other Bathymodiolus species. Molecular analyses of two mitochondrial genes (COI-5 and ND4) were used to characterize the new mussel population from the Gulf of Cadiz (GOC) and to determine their phylogenetic relationships with other members of the " $B$." childressi group. The results indicate that the GOC mussels are conspecific with "Bathymodiolus" mauritanicus Cosel (2002), described from West Africa margin, and support a previous hypothesis that "B." mauritanicus is an amphi-Atlantic species
\end{abstract}

KEY WORDS: deep-sea, mytilids, amphi-Atlantic taxa, mitochondrial DNA

\section{INTRODUCTION}

Exploration of chemosynthetic environments during the past three decades has contributed substantially to the known biodiversity of deep-sea ecosystems, with more than 600 morphological species being described from hydrothermal vents and cold seeps worldwide (Van Dover et al. 2002). The mytilid genus Bathymodiolus Kenk \& Wilson, 1985, and related genera Gigantidas and Tamu within the subfamily Bathymodiolinae (Mollusca: Bivalvia), are among the most widespread of the vent and seep taxa (Fig. 1), comprising 23 named species and six genetically distinct entities distributed in the Atlantic, Pacific and Indian Oceans (Kenk \& Wilson 1985, Cosel et al. 1994, Hashimoto \& Okutani 1994, Cosel et al. 1997, Cosel et al. 1999, Cosel \& Olu 1998, Gustafson et al. 1998, Cosel 2002, Cosel \& Marshall 2003, Hashimoto 2001, Hashimoto \& Yamane 2005, McKiness \& Cavanaugh 2005, McKiness et al. 2005, Sasaki et al. 2005). Long distance dispersal capabilities of bathymodiolins is inferred from observations of small oocytes (40-80 $\mu \mathrm{m})$, large embryonic shells $(100-120 \mu \mathrm{m})$ and larval shells $(380-520 \mu \mathrm{m})$, and from their reproductive dynamics, which together suggest a planktotrophic larval phase that extends for five to six months (Turner et al. 1985, Comtet et al. 2000, Le Pennec \& Beninger, 2000, Colaço et al. 2006, Dixon et al. 2006, Kádár et al. 2006, Tyler et al. 2007). Most bathymodiolins are known to host symbiotic methanotrophs, thiotrophs, or both types of bacteria simultaneously in their gill tissues, but they still retain a filter-feeding ability (Fisher et al. 1987, Page et al. 1991, Pile \& Young 1999). Together, these reproductive and feeding strategies may explain the broad ecological success of bathymodiolin species in chemosynthetic environments.

\footnotetext{
*Corresponding author. E-mail: 1.genio@see.leeds.ac.uk
}

Morphological and molecular phylogenetic studies have identified several natural groupings among species that have been assigned to Bathymodiolus, showing that the genus constitutes a paraphyletic taxon and needs systematic revision (Gustafson et al. 1998, Cosel, 2002, Iwasaki et al. 2006, Jones et al. 2006). Gustafson et al. (1998) first suggested that a new genus name could be used for "Bathymodiolus" childressi and recommended enclosing the genus name in quotation marks until its relationships with other bathymodiolins is better resolved. Researchers have since recognized that "Bathymodiolus" childressi is the first described member of a species complex that is morphologically and genetically distinct from the other Bathymodiolus species. Based on morphological criteria, Cosel (2002) includes three Atlantic species in the "B." childressi species complex: "B." childressi, "B." sp. B (Barbados) and "B." mauritanicus, as well as one NW Pacific species: " $B$." platifrons. Molecular phylogenetic analyses (Jones et al. 2006, Jones \& Vrijenhoek 2006) added more species to this complex: “B." japonicus, “B." hirtus and "B." securiformis from the seeps and vents near Japan, "B." tangaroa from the Kermadec Arc, SW Pacific and Edison Seamount, and " $B$." n. sp. from Edison Seamount. Based on phylogenetic analyses, it remains unclear whether Gigantidas gladius from the Kermadec Arc should also be considered a member of the "B." childressi complex, or its closest relative. Further phylogenetic analyses involving additional morphological and molecular characters are needed to resolve the generic status of this grouping, so for now we continue to refer to members of this complex as "Bathymodiolus."

A new population of bathymodiolin mussels was discovered during the TTR16 research expedition in 2006 to cold seeps and mud volcanoes in the Gulf of Cadiz (GOC), Northeast Atlantic Ocean. A preliminary examination of shell features of the GOC mussels suggested that they are members of "Bathymodiolus" childressi species complex. The geographically closest known members of this complex are “B.” mauritanicus (Cosel, 2002), 


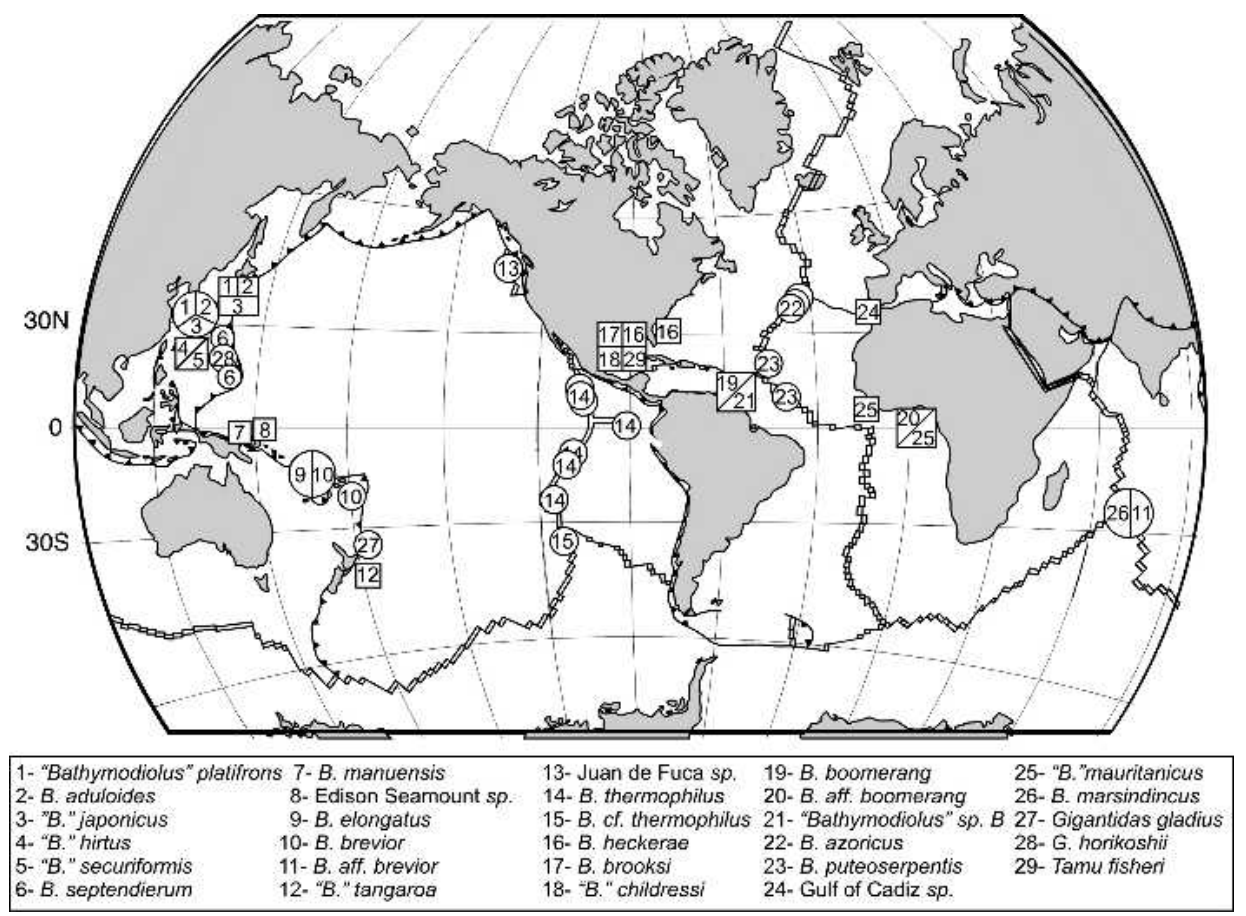

Figure 1. Distribution of described species of the bathymodiolin genus Bathymodiolus (Kenk \& Wilson 1985), Gigantidas (Cosel \& Marshall 2003) and Tamu (Gustafson, Turner, Lutz \& Vrijenhoek 1998) in cold seeps (square symbols) and vent sites (round symbols). Adapted and modified from Tyler \& Young (1999).

from cold seeps along the Angola margin off W. Africa (WAF), and "B." childressi (Gustafson et al. 1998), from Gulf of Mexico (GOM) hydrocarbon seeps. Genetically related "Bathymodiolus" populations also occur on the Barbados Accretionary Prism (BAP) and have been referred to as "Bathymodiolus" sp. B (Cordes et al. 2007, Olu-Le Roy et al. 2007). Molecular studies have revealed that the Barbados mussels are closely related to "B." mauritanicus from the W. Africa margin and are probably conspecific, leading Olu-Le Roy et al. (2007) to hypothesize an amphi-Atlantic distribution for these populations. Here we characterize the GOC mussels genetically and morphologically and examine current hypotheses about the taxonomic status and biogeographic distribution of the Atlantic "Bathymodiolus" species at seep sites.

\section{MATERIALS \& METHODS}

\section{Study Area}

The GOC is located westwards of the Strait of Gibraltar and is under the influence of the eastern end of the cross-Atlantic zonal jet and the Mediterranean inflow/outflow, which strongly influences the local circulation features, particularly because of the generation of the intermediate depth $(750-1,250 \mathrm{~m}) \mathrm{Med}-$ iterranean outflow water mass and the Mediterranean water eddies (Peliz et al. 2006). The GOC (Fig. 2) is presently the most extensive cold seepage area known from the European margins, including a total of over 30 mud volcanoes at depths between 200 and 4,000 m (Pinheiro et al. 2003, Van Rensbergen et al. 2005). To date, biological samples have been collected from 18 of these mud volcanoes, but living mussels are only known from the Darwin mud volcano $(1,115 \mathrm{~m})$, which is covered by large carbonate slabs and crusts. The fissures among the slabs and depressions with scattered crust are filled by abundant shells of "Bathymodiolus" and Neptunea contraria and occasional small clumps of living "Bathymodiolus." Soft corals and other epifauna are occasionally present on the rocks and sediment surface. The extensive mussel graveyards found on the Darwin, Ginsburg $(910 \mathrm{~m})$, Student $(955 \mathrm{~m})$ and Yuma $(975 \mathrm{~m}) \mathrm{mud}$ volcanoes in the western Moroccan field suggest that this was an area of very active seepage, which has now waned. The geological characteristics of the study area are still being investigated (Gutscher et al. 2002, Medialdea et al. 2004, Duarte et al. 2005), but one of the most important structures is a thick (more than $5 \mathrm{~km}$ ) Mio-Pliocene sedimentary sequence emplaced on the structurally complex convergent tectonic setting of the African and Eurasian plate boundary (Hensen et al. 2007). Mud volcanism is triggered mainly by the compressional stress along this boundary. Fluid geochemistry indicates a deep thermogenic source of the fluids caused by clay mineral dehydration followed by fluid mobilization along deeply rooted fault systems (Van Rensbergen et al. 2005, Hensen et al. 2007). The fluids are, on average, highly enriched in methane, but concentrations in the upper $30-\mathrm{cm}$ layer of the sediment vary widely from site to site, and even locally (e.g., Nuzzo et al. 2005). However, the sulphide/methane gradient is usually located at more than $30-\mathrm{cm}$ depth in the sediment and methane concentrations at the sediment/water interface are usually very low.

\section{Sample Collection}

Samples from the top of the Darwin mud volcano (Table 1) were collected with a TV-assisted grab during the TTR 16 cruise aboard the RV Prof. Logachev, and with a suction sampler with 


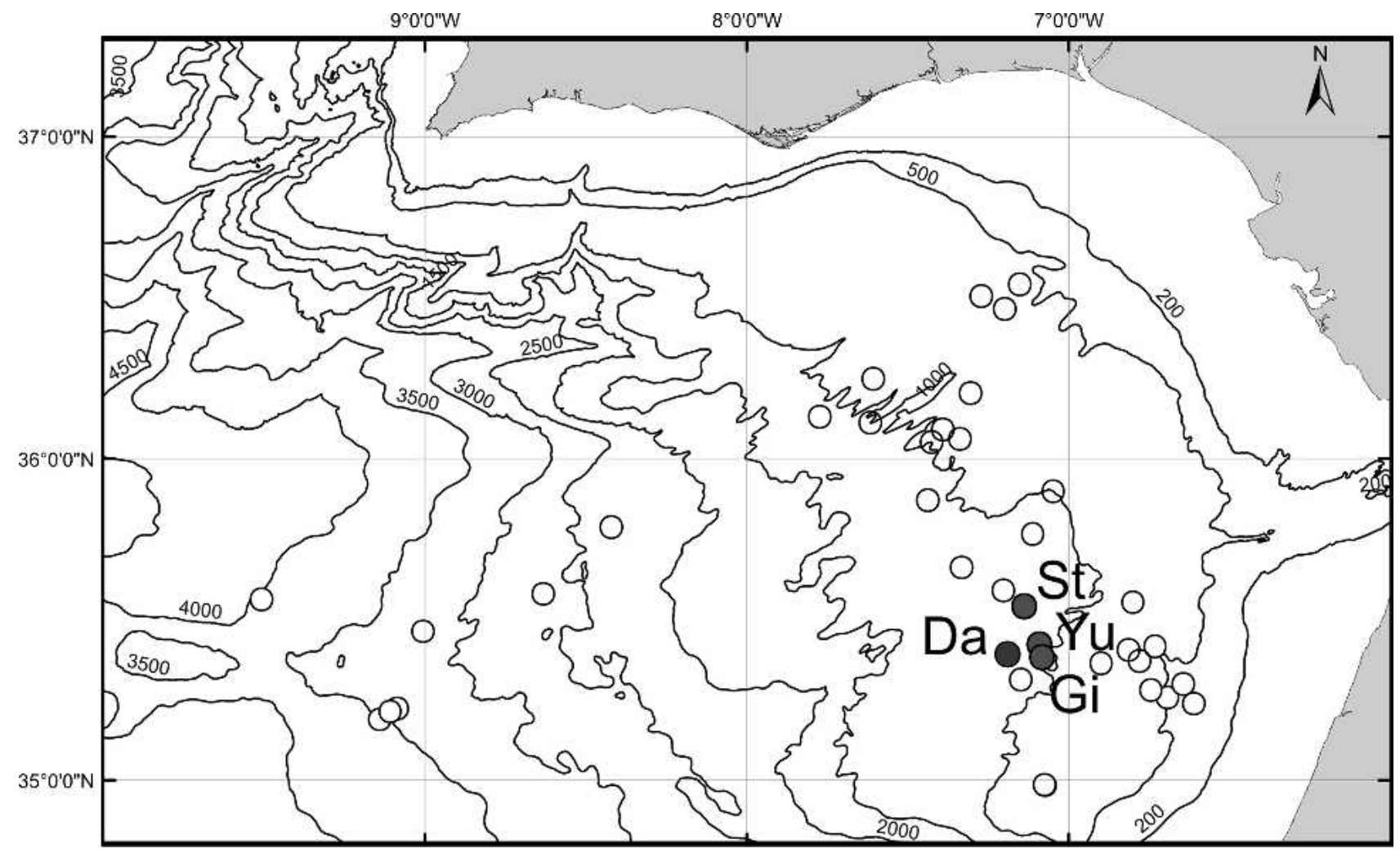

Figure 2. Location of Gulf of Cadiz mud volcanoes (white circles). Living specimens (black) of “Bathymodiolus” sp. were found in Darwin (Da) and empty shells (grey) were observed in Student (St), Yuma (Yu) and Ginsburg (Gi) mud volcanoes.

container mesh size of $2 \mathrm{~mm}$, on Isis ROV Dive 41 during the JC10 cruise aboard the RSS James Cook. Shell morphological observations were made of 15 specimens and compared with previously described species.

For the purposes of this report, we apply the following placeholder names to the operational taxonomic units (OTUs) examined in this study (Table 2): “B." sp. GOC, “B.” childressi GOM ("B." childressi from the Louisiana Slope and Alaminos Canyon), “B.” mauritanicus WAF (West Africa margin), and “B.” sp. BAP (= “B." sp. B from the Barbados Accretionary Prism).

\section{Molecular Methods}

Genomic DNA was isolated with the Qiagen DNeasy DNA extraction kit (Qiagen Inc., Valencia, CA) from adductor mussels from 18 ethanol-preserved specimens. Bathymodiolusspecific primers were designed by C. Braby (Univ. of Oregon) to amplify a $\sim 600$ bp region of the $5^{\prime}$ end of mitochondrial cytochrome c oxidase subunit I (COI-5), the region commonly used for DNA barcoding of invertebrate species (Hebert et al. 2003):

\section{COIG: 5' -GTATTGAATTAGCACGTCCTGGAA-3'} COIH: 5' -ATACTATTCCAAACCCGGGTAAAAT-3' .

We also amplified a $\sim 710$ bp region of mitochondrial NADH dehydrogenase subunit 4 gene (ND4):

Arg BL: 5' -CAAGACCCTTGATTTCGGCTCA-3' (Bielawski \& Gold 1996)

NAP 2H: 5'-TGGAGCTTCTACGTGRGCTTT-3' (Arevalo et al. 1994).

PCR was conducted in a $25 \mu \mathrm{L}$ solution that included 30 $100 \mathrm{ng}$ of template DNA, $2.5 \mu \mathrm{L}$ of $\times 1$ of PCR buffer (supplied by manufacturer), $2.5 \mu \mathrm{L}$ of $2.5 \mu \mathrm{M} \mathrm{MgCl}_{2}, 1 \mu \mathrm{L}$ of each primer (10 $\mu \mathrm{M}$ final conc.), 2.5 units Taq polymerase (AmpliTaq Gold, Applied Biosystems Inc., Foster, CA), $2.5 \mu \mathrm{L}$ of $2 \mathrm{mM}$ stock solution of dNTPs, and sterile water to final volume and occurred with a Cetus 9600 DNA Thermal Cycler (PerkinElmer Corp. CT). We used an initial denaturation of $95^{\circ} \mathrm{C} / 10$ min, followed by 35 cycles of $94^{\circ} \mathrm{C} / 1 \mathrm{~min}, 55^{\circ} \mathrm{C} / 1 \mathrm{~min}$, and $72^{\circ} \mathrm{C} / 1 \mathrm{~min}$, and a final extension at $72^{\circ} \mathrm{C} / 7 \mathrm{~min}$. $\mathrm{PCR}$ products were diluted in $40 \mu \mathrm{L}$ sterile water and cleaned with Multiscreen HTS PCR 96 Filter plates on a vacuum manifold (Millipore

TABLE 1.

Gulf of Cadiz station data.

\begin{tabular}{lllllll}
\hline \hline Cruise & Dive & \multicolumn{1}{c}{ Station } & Latitude & Longitude & Depth & Date \\
\hline TTR16 & & AT608GR & $35^{\circ} 23.531^{\prime} \mathrm{N}$ & $07^{\circ} 11.475^{\prime} \mathrm{W}$ & $1,115 \mathrm{~m}$ & $05 / 31 / 2006$ \\
JC10 & Isis 41 & Stn 076-SUS2 & $35^{\circ} 23.523^{\prime} \mathrm{N}$ & $07^{\circ} 11.479^{\prime} \mathrm{W}$ & $1,109 \mathrm{~m}$ & $06 / 01 / 2007$ \\
\hline
\end{tabular}




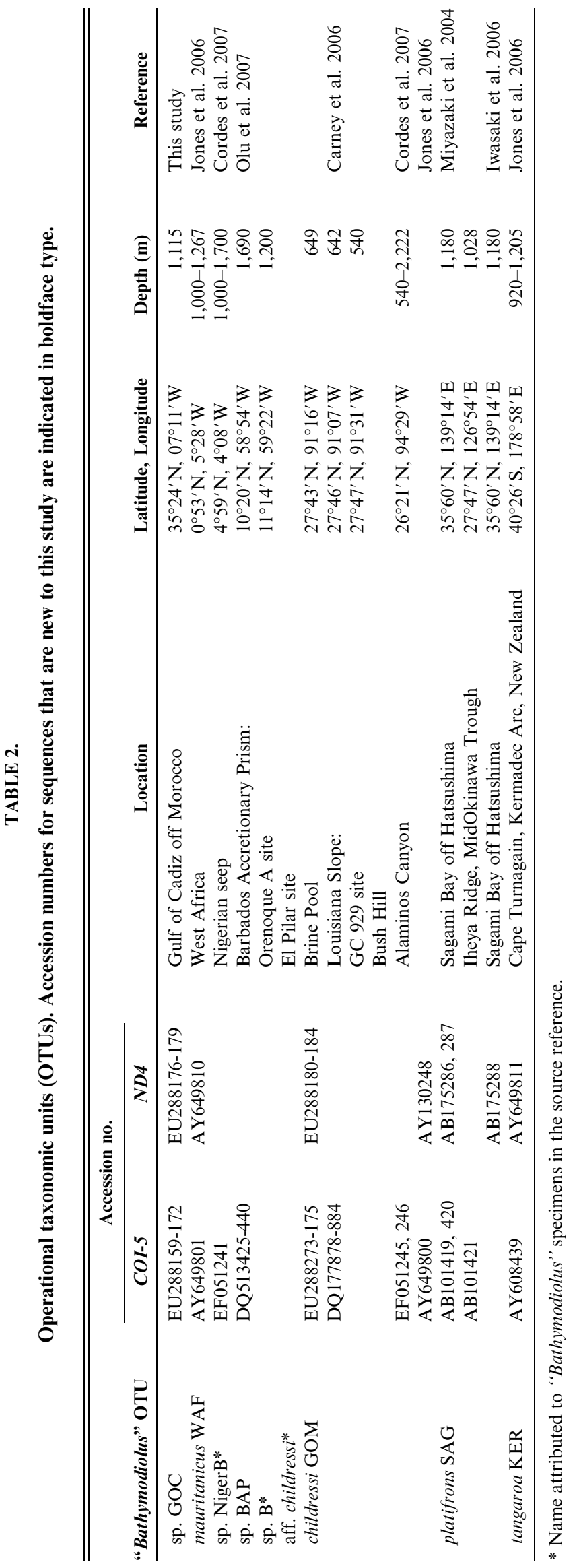

Corp. Billerica, MA). Purified PCR products were sequenced bidirectionally with the same primers used in PCR on an ABI3100 capillary sequencer using BigDye terminator v3.1 chemistry (Applied Biosystems Inc., Foster, CA). DNA sequences were proofread using Sequencher v4.7 (Gene Codes Corp. Inc., Ann Arbor, MI) and edited by eye using Macclade v4.08 (Maddison \& Maddison 2004, Maddison \& Maddison 2005). Statistical analyses were conducted using DNAsp v4.0 (Rozas 2003).

\section{Phylogenetic Analysis}

Phylogenetic analyses were conducted with the program Mr. BAYES v3.1.3 (Huelsenbeck \& Ronquist 2001). Appropriate substitution models for $\mathrm{COI}-5$ and ND4 were determined with standard procedures in PAUP (Swofford 1998) using MrModelTest (www.ebc.uu.se/systzoo/staff/nylander). Bayesian analyses used six chains and were conducted separately for each gene and then in a combined analysis. The combined analyses were partitioned for each gene. After a burn-in period of 2,500 iterations, each analysis was run for 50 million generations and sampled at intervals of 1,000. Each analysis was repeated five times. Output data were visualized using TRACER v1.3 (Rambaut \& Drummond 2003) to determine the appropriate burn-in interval and ensure that the data had reached convergence. Trees were visualized using FigTreE v1.0 (www.tree. bio.ed.ac.uk). Prior phylogenetic analysis of the "Bathymodiolus" childressi complex (Jones and Vrijenhoek 2006) revealed that the most appropriate outgroups for our analyses are " $B$." platifrons and "B." tangaroa, for which COI-5 and ND4 sequences were already available (Table 2).

\section{RESULTS}

\section{Morphological Observations of Shells}

The Gulf of Cadiz mussels, "Bathymodiolus" sp. GOC, exhibit shell features (Fig. 3) that generally characterize the “B.' childressi group, as provisionally defined by Cosel (2002). They have terminal umbones, a rather narrow anterior margin and a broad posterior part that give the valves a wedge-shaped outline. They have a very small anterior adductor scar, a continuous posterior byssus retractor scar and an anterior retractor scar that is situated in the posterior part of the umbonal cavity behind the beaks. " $B$." sp. GOC possesses a thick and solid shell, much like "B." mauritanicus and "B." sp. BAP, whereas " $B$." childressi GOM and "B." platifrons have thin and fragile shells. Like “B." mauritanicus WAF and "B." platifrons, " $B$." sp. GOC possesses an anteriorly situated terminal umbone with the distance from anterior shell margin to anterior edge of umbo being $<1 \mathrm{~mm}$ in small specimens and $1-2 \mathrm{~mm}$ in larger specimens. In contrast, “ $B$.” childressi GOM and “ $B$.” sp. BAP have slightly subterminal umbones. In addition to their anterior location, the umbones of " $B$." sp. GOC are broad and somewhat flattened, a characteristic shared by "B." mauritanicus WAF and "B." sp. BAP.

\section{Mitochondrial DNA Analyses}

Our genetic analyses of 18 “ $B$.” sp. GOC mussel specimens generated 14 novel COI-5 sequences of $\sim 531$ bp length 


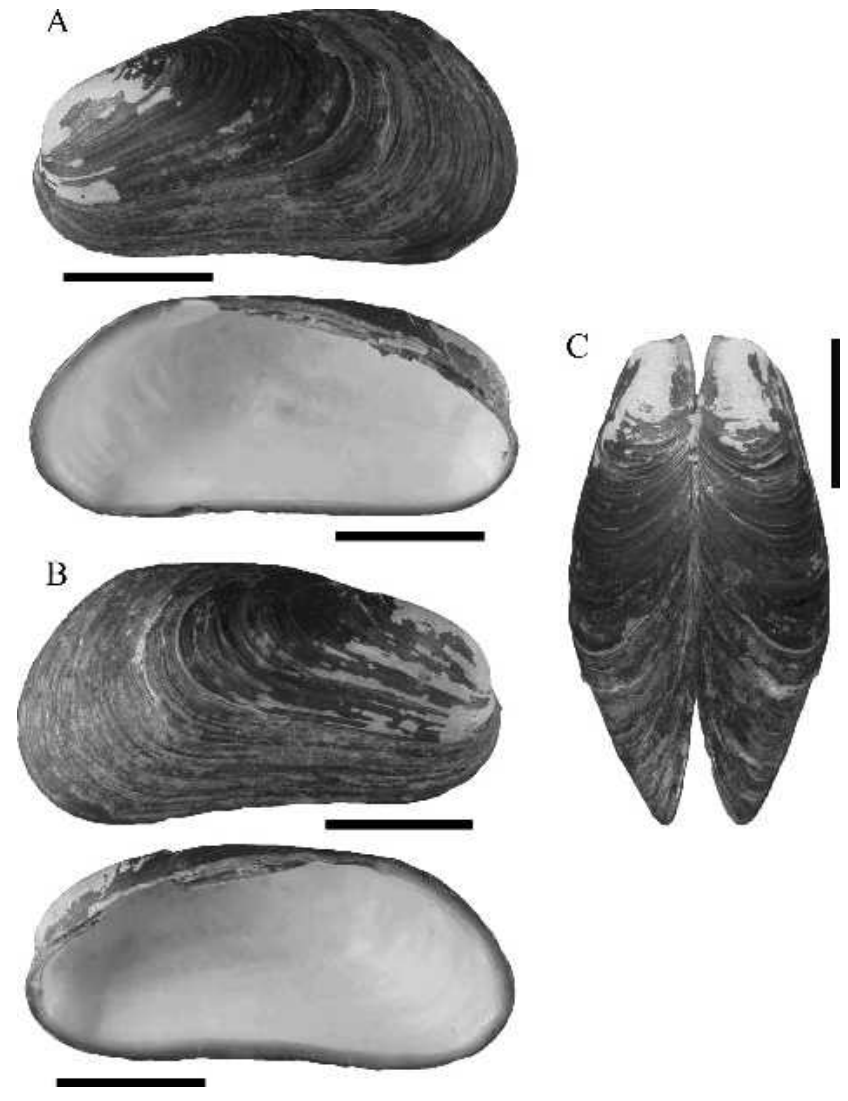

Figure 3. Gulf of Cadiz "Bathymodiolus" sp. (a) Exterior and interior view of left valve, (b) exterior and interior view of right valve, (c) dorsal view. Scale bar $1 \mathrm{~cm}$.

(GenBank accession numbers EU288159 to EU288172). For comparative purposes (Table 2), we trimmed our sequences to $372 \mathrm{bp}$ to match the length of published sequences for other "Bathymodiolus." This length of COI-5 exhibited 18 polymorphic sites, four as singletons and 14 as parsimony-informative sites. The same 18 specimens generated eight novel ND4 sequences that we trimmed to $456 \mathrm{bp}$ length for comparative purposes (GenBank accession numbers EU288176 to EU288179). The ND4 sequences exhibited 43 polymorphic sites, 25 as singletons and 18 as parsimony-informative sites. The best-fit substitution model, according to the AIC criterion (Akaike 1974), was the HKY + SS for both COI-5 and ND4, when treated separately. But for the combined analyses, GTR + $\mathrm{I}+\mathrm{G}$ provided the best fit.

Pairwise comparisons of sequence divergence between different OTUs ( $d_{b}$; Table 3 ) revealed that “ $B$." sp. GOC was very similar to both " $B$." mauritanicus WAF $\left(d_{b}=0.04 \%\right.$ for $C O I-5$ and $d_{b}=0.65 \%$ for $\left.N D 4\right)$ and “ $B$." sp. BAP $\left(d_{b}=0.42 \%\right.$ for COI-5). These divergence values were comparable with the values seen within OTUs for which we had adequate sample sizes: "B." childressi GOM, $d_{w}=1.06 \%$ for COI-5 and $d_{w}=$ $0.39 \%$ for $N D 4$; “ $B$. ” sp. BAP, $d_{w}=0.70 \%$ for $C O I-5$. Sequence divergence among other OTUs was higher among the named OTUs, “B." tangaroa, "B." platifrons, "B." childressi GOM, and "B." mauritanicus WAF, which differed minimally by $1.41 \%$ for $C O I-5$ and $3.83 \%$ for ND4. The two Pacific species "B." tangaroa and "B." platifrons were the most divergent taxa with respect to $N D 4$.

The three phylogenetic trees yielded essentially the same topologies, therefore we show the combined tree of COI-5 and ND4 genes (Fig. 4). Phylogenetic analyses identified a wellsupported grouping that included all the Atlantic OTUs: " $B$." childressi GOM, "B." mauritanicus WAF, "B." sp. BAP and “B." sp. GOC. Within this grouping, "B." childressi GOM is clearly differed from the W. Atlantic species, which all clustered together. " $B$." sp. GOC could not be discriminated from " $B$." mauritanicus WAF or “ $B$.” sp. BAP.

\section{DISCUSSION}

In addition to the morphological observations of the shell features, mitochondrial DNA sequences from two genes (COI-5 and ND4) showed that the GOC mussels are essentially identical with "Bathymodiolus" mauritanicus Cosel (2002), from

TABLE 3.

Mean sequence divergence within (on diagonal) and between "Bathymodiolus” Operation Taxonomic Units (OTUs). Names are followed by 3-letter abbreviations for sample locality: GOC, Gulf of Cadiz; WAF, West Africa margin; BAP, Barbados Accretionary Prism; GOM, Gulf of Mexico; SAG, Sagami Bay; KER, Kermadec Arc. Sample sizes are given in parentheses after each gene.

\begin{tabular}{|c|c|c|c|c|c|c|}
\hline $\begin{array}{c}\text { "Bathymodiolus" } \\
\text { species }\end{array}$ & $\begin{array}{l}\text { sp. } \\
\text { GOC }\end{array}$ & $\begin{array}{c}\text { mauritanicus } \\
\text { WAF }\end{array}$ & $\begin{array}{l}\text { sp. } \\
\text { BAP }\end{array}$ & $\begin{array}{c}\text { childressi } \\
\text { GOM }\end{array}$ & $\begin{array}{l}\text { platifrons } \\
\text { SAG }\end{array}$ & $\begin{array}{c}\text { tangaroa } \\
\text { KER }\end{array}$ \\
\hline COI-5 & $(15)$ & (2) & (16) & (10) & (4) & (1) \\
\hline sp. GOC & 0.0008 & & & & & \\
\hline mauritanicus WAF & 0.0004 & 0.0000 & & & & \\
\hline sp. BAP & 0.0042 & 0.0038 & 0.0070 & & & \\
\hline childressi GOM & 0.0498 & 0.0494 & 0.0533 & 0.0106 & & \\
\hline platifrons SAG & 0.0145 & 0.0141 & 0.0180 & 0.0605 & 0.0040 & \\
\hline tangaroa KER & 0.0697 & 0.0693 & 0.0701 & 0.1045 & 0.0586 & 0.0000 \\
\hline$N D 4$ & $(15)$ & (2) & $(0)$ & $(10)$ & (4) & (1) \\
\hline sp. GOC & 0.0019 & & & & & \\
\hline mauritanicus WAF & 0.0065 & 0.0000 & - & & & \\
\hline childressi GOM & 0.0383 & 0.0402 & - & 0.0039 & & \\
\hline platifrons SAG & 0.0669 & 0.0704 & - & 0.0863 & 0.0000 & \\
\hline tangaroa KER & 0.2555 & 0.2554 & - & 0.2513 & 0.2602 & 0.0000 \\
\hline
\end{tabular}


the W. Africa margin. These DNA sequences also confirmed that the mussels from the Barbados Accretionary Prism (" $B$." sp. B of Olu-Le Roy et al. 2007) are very close to " $B$." mauritanicus. All pairwise distances among the three OTUs were comparable with sequence divergence within adequately sampled OTUs. Consequently, we consider the Gulf of Cadiz and Barbados populations of these mussels as conspecific with "B." mauritanicus, a result that clearly supports the hypothesis of Olu-Le Roy et al. (2007) that "B." mauritanicus is an "amphiAtlantic species".

"Bathymodiolus" childressi from the Gulf of Mexico (Louisiana Slope and Alamiños Canyon off Texas) does differ from the three "B." mauritanicus OTUs. However, divergence levels were relatively low (COI-5: 4.94-5.3\%; and ND4: 3.83-4.02\%) compared with divergence between pairs of other named bathymodiolin species, which typically are greater than $10 \%$

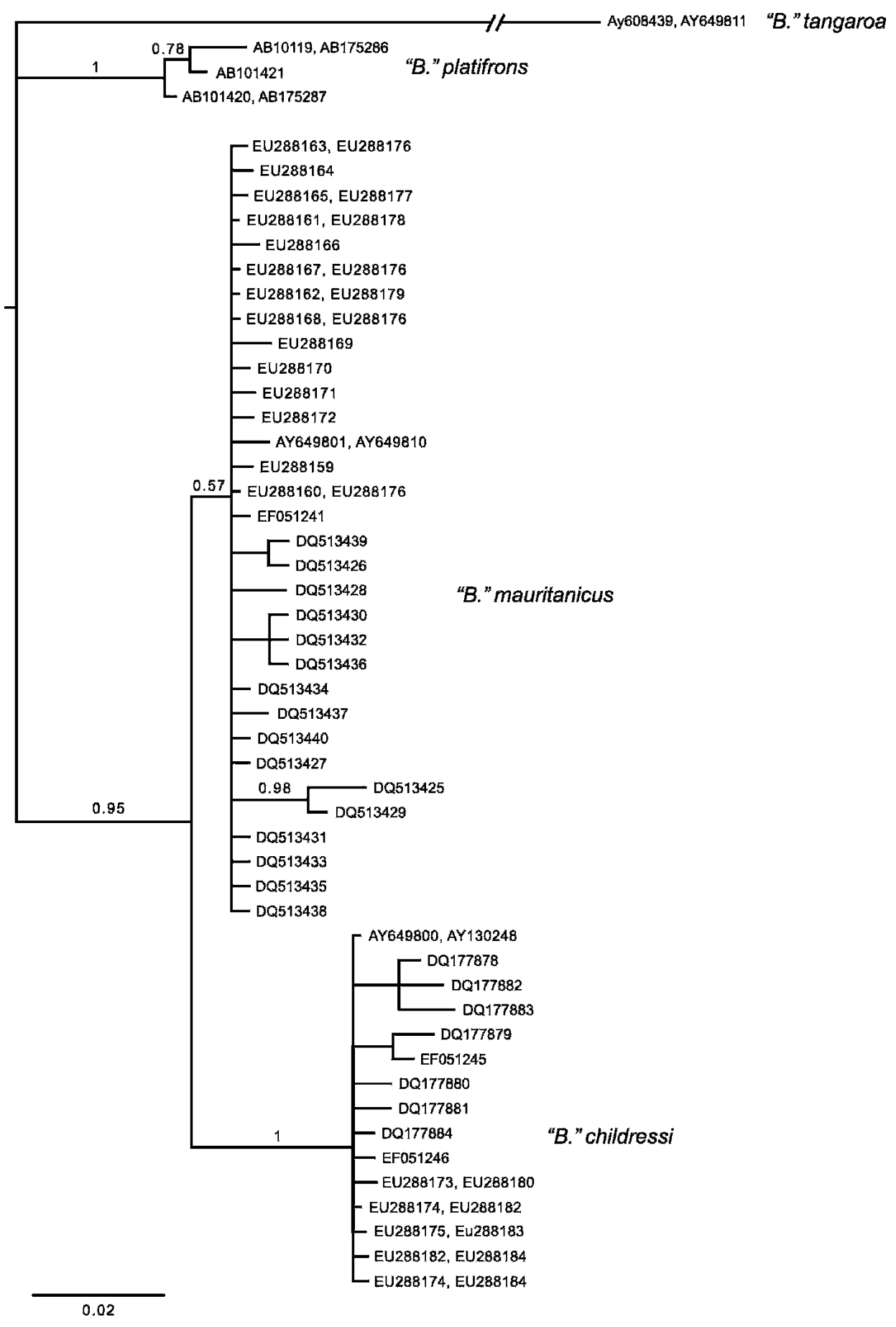

Figure 4. Bayesian tree of $\mathrm{COI}-5$ and ND4 combined dataset. Scale bar indicates percent sequence divergence. Bayesian posterior probabilities (BPP) are shown. 
(Jones \& Vrijenhoek 2006). Yet, the COI-5 divergence level between "B." mauritanicus and "B." childressi was very similar to that found between the sister-species Bathymodiolus thermophilus and $B$. aff. thermophilus $(\sim 4.4 \%)$ from the East Pacific Rise vent sites (Won et al. 2003). Although Olu-Le Roy et al. (2007) reported the same pattern of mitochondrial divergence between their "B." sp. B (Barbados) and "B." childressi, they puzzled over the identity of these taxa because they shared identical nuclear ribosomal ITS 2 sequences. However, ongoing comparisons of sister-species pairs of mussels for ITS2 ( $B$. azoricus versus $B$. puteoserpentis and $B$. thermophilus versus $B$. aff. thermophilus) have also failed to find divergence (Y. J. Won, personal communication). This untranscribed spacer region of the nuclear ribosomal operon is conserved in many taxa, and appears not to be a reliable marker of species divergence in mussels.

Several genetic studies have investigated gene flow among deep-sea mussel populations at chemosynthetic provinces (Craddock et al. 1995, Vrijenhoek 1997, Comtet \& Desbruyères 1998, O'Mullan et al. 2001, Won et al. 2003, Carney et al. 2006), but the mechanisms that lead to the observed diversity of bathymodiolins are not yet fully understood. Won et al. (2003) suggested that the formation of the Easter Microplate could have created a geographical barrier between mussel populations along the East Pacific Rise (EPR), leading to the evolution of the sister species $B$. thermophilus and $B$. aff. thermopilus north $\left(7^{\circ} \mathrm{C}-17^{\circ} \mathrm{S}\right)$ and south $\left(31^{\circ} \mathrm{C}-32^{\circ} \mathrm{S}\right)$ of the microplate, respectively. However, Won et al. (2003) found no evidence for isolation-by-distance between Galapagos Rift and EPR $\left(13^{\circ} \mathrm{N}\right.$ to $\left.11^{\circ} \mathrm{S}\right)$ populations, which appear to be genetically homogeneous. A similar study of the mussel populations distributed along the Mid-Atlantic Ridge vent sites revealed a hybrid zone between the two mussel species, B. azoricus and $B$. puteoserpentis (O'Mullan et al. 2001). The recent study by Carney et al. (2006) of “ $B$." childressi populations occurring at hydrocarbon and brine seeps in the Gulf of Mexico revealed that these populations are not differentiated genetically, despite the broad range of depths at which they occur (540-2,200 m). Moreover, trans-Atlantic larval dispersal across the equatorial belt region was suggested to explain the occurrence of genetically related "Bathymodiolus" populations at West Africa and Barbados seeps (Cordes et al. 2007, Olu-Le Roy et al. 2007). A limited analysis of the GOC population shows that mussels were undergoing reproduction and that all specimens examined were in the early stage of gametogenesis (P. Tyler, unpublished data). These observations suggest a seasonal pattern correlated with surface primary production, as seen in " $B$." childressi (Tyler et al. 2007) and B. azoricus (Colaço et al. 2006, Dixon et al. 2006). Such reproductive patterns give further support to the high dispersal capabilities of the planktotrophic larvae of bathymodiolin species. Together, these studies show that there is not a single pattern for species differentiation among chemosynthetic mussels and that habitat specific biotic and physical characteristics may play important roles, leading to population divergence at vents and seeps and subsequent speciation events.

The discovery of "B." mauritanicus at the Gulf of Cadiz mud volcanoes not only constitutes the northernmost record for this species in the NE Atlantic, but also gives new insights into the biogeographic distribution of " $B$." childressi group of mussels. The current phylogeny of " $B$." childressi group (Jones \&
Vrijenhoek 2006) shows that the basal members live in the West Pacific Ocean, whereas the more derived members live in the Atlantic, suggesting the group has diversified from the Pacific to the Atlantic. Here we consider three possible routes for this diversification. One is via the Tethys seaway, which previously linked the Indo-Pacific and Atlantic Oceans and closed during the early Cenozoic by the movement of Africa and India towards Eurasia. There were plenty of seep habitats in the western Tethys area during the Cenozoic, as evidenced by the many Miocene communities in the Apennine region of Italy (Taviani 2001, 2003). Before the Messinian Salinity Crisis at the end of the Miocene, these communities strongly resembled modern seep communities in the West Africa and Gulf of Mexico, containing large mussels, possibly related to Bathymodiolus. However, after the salinity event and the disappearance of deep corridors between the Mediterranean and the Atlantic basins, Mediterranean seep communities developed a distinctive character, lacking several representatives of the typical oceanic cold seep communities, such as the large mussels, large vesicomyid clams, and provannid gastropods (Taviani 2003, Olu-Le Roy et al. 2004, Salas et al. 2004).

A second possible Pacific-to-Atlantic diversification route for the "B." childressi group was through the Central America region before the closure of the Isthmus of Panama, around five million years ago. This may be supported by the presence of the oldest known representatives of bathymodiolins from Eocene to Oligocene seeps in Washington State, USA (Kiel 2006, Kiel \& Little 2006) and bathymodiolin fossils from Paleogene and Neogene seeps in the Caribbean region (Gill et al. 2005, Kiel \& Peckmann 2007). Finally, a more recent colonization of the Atlantic seep sites by the "B." childressi group may have occurred around the African margins, as has been recently suggested for species of Calyptogena (Krylova \& Sahling 2006).

As well as being the most geographically diverse assemblage of the deep-sea mussel species, the "B." childressi complex contains species living at both cold seeps and hydrothermal vents, such as "B." platifrons and "B." japonicus. Further biogeographic analyses and population genetic studies of all the Pacific and Atlantic populations of the "B." childressi species complex will help to understand better their evolutionary history and to resolve current systematic problems within this taxon.

\section{ACKNOWLEDGMENTS}

The lead author was supported by the PhD grant FCT-SFRH/ BD/23231/2005 and thanks the Systematics Research Fund and the Conchological Society of Great Britain and Ireland for logistical funding for this research. Molecular studies were supported by grants from the David \& Lucile Packard Foundation and the US National Science Foundation (OCE0241613) to MBARI. The authors thank the chief scientists, captains and crew of the oceanographic cruises that collected specimens for this study, namely TTR16 Leg 2 (RV Prof. Logachev, Training Through Research Programme) and JC10 Leg 1 (RSS James Cook, National Oceanography Center, Southampton). These cruises were partially supported by the HERMES project, EC contract GOCE-CT-2005-511234, funded by the European Commission's Sixth Framework Programme under the priority "Sustainable Development, Global Change and Ecosystems" and the Natural Environment Research Council (UK). 


\section{LITERATURE CITED}

Akaike, H. 1974. A new look at the statistical model identification. IEEE Trans. Autom. Contr. 19:716-723.

Arevalo, E., S. K. Davis \& J. W. Sites. 1994. Mitochondrial-DNA sequence divergence and phylogenetic relationships among 8 chromosome races of the Sceloporus-Grammicus complex (Phrynosomatidae) in Central Mexico. Syst. Biol. 43:387-418.

Bielawski, J. P. \& J. R. Gold. 1996. Unequal synonymous substitution rates within and between two protein-coding mitochondrial genes. Mol. Biol. Evol. 13:880-992.

Carney, S. L., M. I. Formica, H. Divatia, K. Nelson, C. R. Fisher \& S. W. Schaeffer. 2006. Population structure of the mussel "Bathymodiolus" childressi from Gulf of Mexico hydrocarbon seeps. . Deepsea Res. 53:1061-1072.

Colaço, A., I. Martins, M. Laranjo, L. Pires, C. Leal, C. Prieto, V. Costa, H. Lopes, D. Rosa, P. R. Dando \& R. S. Santos. 2006. Annual spawning of the hydrothermal vent mussel, Bathymodiolus azoricus, under controlled aquarium, conditions at atmospheric pressure. J. Exp. Mar. Biol. Ecol. 333:166-171.

Comtet, T. \& D. Desbruyères. 1998. Population structure and recruitment in mytilid bivalves from the Lucky Strike and Menez Gwen hydrothermal fields $\left(37^{\circ} 17^{\prime} \mathrm{N}\right.$ and $37^{\circ} 50^{\prime} \mathrm{N}$ on the Mid-Atlantic Ridge). Mar. Ecol. Prog. Ser. 163:165-177.

Comtet, T., D. Jollivet \& D. R. Dixon. 2000. Molecular and morphological identification of settlement-stage vent mussel larvae, Bathymodiolus azoricus (Bivalvia: Mytilidae), preserved in situ at active vent fields on the Mid-Atlantic Ridge. Limnol. Oceanogr. 45:1655-1661.

Cordes, E. E., S. L. Carney, S. Hourdez, R. S. Carney, J. M. Brooks \& C. R. Fisher. 2007. Cold seeps of the deep Gulf of Mexico: Community structure and biogeographic comparisons to Atlantic equatorial belt seep communities. Deep-sea Res. I 54:637-653.

Craddock, C., W. R. Hoeh, R. A. Lutz \& R. C. Vrijenhoek. 1995. Extensive gene flow in the deep-sea hydrothermal vent mytilid Bathymodiolus thermophilus. Mar. Biol. 124:137-146.

Dixon, D. R., D. M. Lowe, P. I. Miller, G. R. Villemin, A. Colaço, R. Serrão-Santos \& L. R. J. Dixon. 2006. Evidence of seasonal reproduction in the Atlantic vent mussel Bathymodiolus azoricus, and apparent link with the timing of photosynthetic primary production. J. Mar. Biol. Assn. UK 86:1363-1371.

Duarte, J. C., F. Rosas, L. M. Pinheiro, L. M. Matias, A. M. Carvalho, P. Terrinha \& I. Ivanov. 2005. Interpretation of recent sedimentary and tectonic structures off SW Iberia from multibeam bathymetry, seismic reflection and experimental modeling. Geophys. Res. Abstr. 7:07867.

Gill, F. L., I. C. Harding, C. T. S. Little \& J. A. Todd. 2005. Paleogene and Neogene cold seep communities in Barbados, Trinidad and Venezuela: An overview. Palaeogeogr. Palaeoclimatol. Palaeoecol. 227:191-209.

Gustafson, R. G., R. D. Turner, R. A. Lutz \& R. C. Vrijenhoek. 1998. A new genus and five species of mussels (Bivalvia, Mytilidae) from deep-sea sulfide/hydrocarbon seeps in the Gulf of Mexico. Malacologia 40:63-113.

Gutscher, M.-A., J. Malod, J.-P. Rehault, I. Contrucci, F. Klingelhoefer, L. Mendes-Victor \& W. Spakman. 2002. Evidence for active subduction beneath Gibraltar. Geology 30:1071-1074.

Fisher, C. R., J. J. Childress, R. S. Oremland \& R. R. Bidigare. 1987. The importance of methane and thiosulfate in the metabolism of the bacterial symbionts of two deep-sea mussels. Mar. Biol. 96:59-71.

Hashimoto, J. \& T. Okutani. 1994. Four new mytilid mussels associated with deep-sea chemosynthetic communities around Japan. Venus Jap. J. Malac. 53:61-83.

Hashimoto, J. 2001. A new species of Bathymodiolus (Bivalvia: Mytilidae) from hydrothermal vent communities in the Indian Ocean. Venus 60:141-149.

Hashimoto, J. \& T. Yamane. 2005. A new species of Gigantidas (Bivalvia:Mytilidae) from a vent site on the Kaikata Seamount
Southwest of the Ogasawara (Bonin) Islands, Southern Japan. Venus 64:1-10.

Hebert, P. D. N., A. Cywinska, S. L. Ball \& J. R. deWaard. 2003. Biological identifications through DNA barcodes. Proc. Biol. Sci. 270:313-321.

Hensen, C., M. Nuzzo, E. Hornibrook, L. Pinheiro, B. Bock, V. Magalhaes \& W. Brückmann. 2007. Sources of mud volcano fluids in the Gulf of Cadiz - indications for hydrothermal imprints. Geochim. Cosmochim. Acta. 71:1232-1248.

Huelsenbeck, J. P. \& F. Ronquist. 2001. MRBAYES: Bayesian inference of phylogenetic trees. Bioinformatics 17:754-755.

Iwasaki, H., A. Kyuno, M. Shintaku, Y. Fujita, Y. Fujiwara, K. Fujikura, J. Hashimoto, L. O. Martins, A. Gebruk \& J.-I. Miyazaki. 2006. Evolutionary relationships of deep-sea mussels inferred by mitochondrial DNA sequences. Mar. Biol. 149:1111-1122.

Jones, W. J. \& R. C. Vrijenhoek. 2006. Evolutionary relationships within the "Bathymodiolus" childressi group. Cah. Biol. Mar. 47:403-407.

Jones, W. J., Y. J. Won, P. A. Y. Maas, P. J. Smith, R. A. Lutz \& R. C. Vrijenhoek. 2006. Evolution of habitat use by deep-sea mussels. Mar. Biol. 148:841-851.

Kádár, E., A. Lobo-da-Cunha, R. S. Santos \& P. Dando. 2006. Spermatogenesis of Bathymodiolus azoricus in captivity matching reproductive behaviour at deep-sea hydrothermal vents. J. Exp. Mar. Biol. Ecol. 335:19-26.

Kenk, V. C. \& B. R. Wilson. 1985. A new mussel (Bivalvia, Mytilidae) from hydrothermal vents in the Galapagos Rift zone. Malacologia 26:253-271.

Kiel, S. 2006. New records and species of mollusks from Tertiary coldseep carbonates in Washington State, USA. J. Paleont. 80:121137.

Kiel, S. \& C. T. S. Little. 2006. Cold seep mollusks are older than the general marine mollusk fauna. Science 313:1429-1431.

Kiel, S. \& J. Peckmann. 2007. Chemosymbiotic bivalves and stable carbon isotopes indicate hydrocarbon seepage at four unusual Cenozoic fossil localities. Lethaia 40:345-357.

Krylova, E. M. \& H. Sahling. 2006. Recent bivalve mollusks of the genus Calyptogena (Vesicomyidae). J. Mollusc. Stud. 72:359395.

Le Pennec, M. \& P. G. Beninger. 2000. Reproductive characteristics and strategies of reducing-system bivalves. Comp. Biochem. Physiol. A Mol. Integr. Physiol. 126:1-16.

Maddison, D. R. \& W. P. Maddison. 2004. Mesquite, version 1.04 (build g21). Tucson, AZ. http://mesquiteproject.org

Maddison, W. P. \& D. R. Maddison. 2005. MacClade (Ver. 4.0): computer program for phylogenetic analysis. Sunderland, MA: Sinauer Associates, Inc.

McKiness, Z. P. \& C. M. Cavanaugh. 2005. The ubiquitous mussel: Bathymodiolus aff. brevior symbiosis at the Central Indian Ridge hydrothermal vents. Mar. Ecol. Prog. Ser. 295:183-190.

McKiness, Z. P., E. R. McMullin, C. R. Fisher \& C. M. Cavanaugh. 2005. A new bathymodioline mussel symbiosis at the Juan de Fuca hydrothermal vents. Mar. Biol. 148:109-116.

Medialdea, T., R. Vegas, L. Somoza, J. T. Vazquez, A. Maldonaldo V. Diaz-del-Rio, et al. 2004. Structure and evolution of the 'olistostrome' complex of the Gibraltar Arc in the Gulf of Cadiz (eastern Central Atlantic): evidence from two long seismic cross-sections. Mar. Geol. 209:173-198.

Miyazaki, J.-I., M. Shintaku, A. Kyuno, Y. Fujiwara, J. Hashimoto \& H. Iwasaki. 2004. Phylogenetic relationships of deep-sea mussels of the genus Bathymodiolus (Bivalvia: Mytilidae). Mar. Biol. 144:527535 .

Nuzzo, M., C. Hensen, E. Hornibrook, W. Brueckmann, V. Magalhães, R. Parkes \& L. Pinheiro. 2005. Origin of mud volcano fluids in the Gulf of Cadiz (E-Atlantic). EGU General Assembly. 
Olu-Le Roy, K., M. Sibuet, A. Fiala-Médioni, S. Gofas, C. Salas, A. Mariotti, J.-P.I. Foucher \& J. Woodside. 2004. Cold seep communities in the deep eastern Mediterranean Sea: composition, symbiosis and spatial distribution on mud volcanoes. Deep-sea Res. I 51:1915-1936.

Olu-Le Roy, K., R. v. Cosel, S. Hourdez, S. L. Carney \& D. Jollivet. 2007. Amphi-Atlantic cold-seep Bathymodiolus species complexes across the equatorial belt. Deep-sea Res. I 54:1890-1911.

O'Mullan, G. D., P. A. Y. Maas, R. A. Lutz \& R. C. Vrijenhoek. 2001. A hybrid zone between hydrothermal vent mussels (Bivalvia: Mytilidae) from the Mid-Atlantic Ridge. Mol. Ecol. 10:2819-2831.

Page, H. M., A. Fiala-Medioni, C. R. Fisher \& J. J. Childress. 1991. Experimental evidence for filter-feeding by the hydrothermal vent mussel, Bathymodiolus thermophilus. Deep-sea Res. I 38:14551461.

Peliz, A., A. M. Teles-Machado, J. Dubert, P. Marchesiello \& R. Sanchez. 2006. Surface circulation in the Gulf of Cadiz: The different processes at play in a modeling study. Geophys. Res. Abstr. 8:02969.

Pile, A. J. \& C. M. Young. 1999. Plankton availability and retention efficiencies of cold-seep symbiotic mussels. Limnol. Oceanogr. 44:1833-1839.

Pinheiro, L. M., M. K. Ivanov, A. Sautkin, G. Akhmanov, V. H. Magalhães, A. Volonskaya, J. H. Monteiro, L. Somoza, J. Gardner, N. Hamouni \& M. R. Cunha. 2003. Mud volcanism in the Gulf of Cadiz: results from the TTR-10 cruise. Mar. Geol. 195:131-151.

Rambaut, A. \& A. Drummond. 2003. Tracer: a program for analysing results from Bayesian MCMC programs such as BEAST \& MrBayes. Oxford, UK. http://evolve.zoo.ox.ac.uk/software.html?id=tracer

Rozas, J., J. C. Sánchez-DelBarrio, X. Messeguer \& R. Rozas. 2003. DnaSP, DNA polymorphism analyses by the coalescent and other methods. Bioinformatics 19:2496-2497.

Salas, C., A. Mariotti, J.-P. Foucher \& J. Woodside. 2004. Cold seep communities in the deep eastern Mediterranean Sea: composition, symbiosis and spatial distribution on mud volcanoes. Deep-sea Res. I 51:1915-1936.

Sasaki, T., T. Okutani \& K. Fujikura. 2005. Molluscs from hydrothermal vents and cold seeps in Japan: a review of taxa recorded in twenty recent years (1984-2004). Venus Jap. J. Malac. 64:87-133.

Swofford, D. L. 1998. PAUP*. Phylogenetic analysis using parsimony (*and other methods). Sunderland, MA: Sinauer.

Taviani, M. 2001. Fluid venting and associated processes. In: G. B. Vai \& I. P. Martini, editors. Anatomy of an Orogen: the Apennines and adjacent Mediterranean basins. Great Britain: Kluwer Academic Publishers. pp. 351-366.
Taviani, M. 2003. Shaping the biogeography of the Mediterranean basin: one geologist's perspective. Biogeographia 14:15-22.

Turner, R. D., R. A. Lutz \& D. Jablonski. 1985. Modes of molluscan larval development at deep-sea hydrothermal vents. Bull. Biol. Soc. Wash. Bull. 6:167-184.

Tyler, P. A. \& C. M. Young. 1999. Reproduction and dispersal at vents and cold seeps. J. Mar. Biol. Assn. UK. 79:193-208.

Tyler, P., C. M. Young, E. Dolan, S. M. Arellano, S. D. Brooke \& M. Baker. 2007. Gametogenic periodicity in the chemosynthetic cold-seep mussel "Bathymodiolus" childressi. Mar. Biol. 150:829840.

Van Rensbergen, P., D. Depreiter, B. Pannemans, G. Moerkerke, D. Van Rooij, B. Marsset, G. Akhmanov, V. Blinova, M. Ivanov, M. Rachidi, V. Magalhaes, L. Pinheiro, M. Cunha \& J.-P. Henriet. 2005. The El Arraiche mud volcano field at the Moroccan Atlantic slope, Gulf of Cadiz. Mar. Geol. 219:1-17.

Von Cosel, R. 2002. A new species of bathymodioline mussel (Mollusca, Bivalvia, Mytilidae) from Mauritania (West Africa), with comments on the genus Bathymodiolus Kenk \& Wilson, 1985. Zoosystema 24:259-271.

Von Cosel, R., T. Comtet \& E. Krylova. 1997. Two new species of Bathymodiolus from hydrothermal vents on the Mid-Atlantic Ridge. Cah. Biol. Mar. 38:145-146.

Von Cosel, R., T. Comtet \& E. Krylova. 1999. Bathymodiolus (Bivalvia: Mytilidae) from hydrothermal vents on the Azores Triple Junction and the Logatchev Hydrothermal Field, Mid-Atlantic Ridge. Veliger 42:218-248.

Von Cosel, R.,. \& B. A. Marshall. 2003. Two new species of large mussels (Bivalvia: Mytilidae) from active submarine volcanoes and a cold seep off the eastern North Island of New Zealand, with description of a new genus. Nautilus 117:31-46.

Von Cosel, R., B. Métivier \& J. Hashimoto. 1994. Three new species of Bathymodiolus (Bivalvia: Mytilidae) from hydrothermal vents in the Lau Basin and the Fiji Basin, Western Pacific, and the Snake Pit Area, Mid-Atlantic Ridge. Veliger 37:374-392.

Von Cosel, R. \& K. Olu. 1998. Gigantism in Mytilidae. A new Bathymodiolus from cold seep areas on the Barbados Accretionary Prism. Animal Biol. 321:655-663.

Vrijenhoek, R. C. 1997. Gene flow and genetic diversity in naturally fragmented metapopulations of deep-sea hydrothermal vent animals. J. Hered. 88:285-293.

Won, Y., C. R. Young, R. A. Lutz \& R. C. Vrijenhoek. 2003. Dispersal barriers and isolation among deep-sea mussel populations (Mytilidae: Bathymodiolus) from eastern Pacific hydrothermal vents. Mol. Ecol. 12:169-184. 